\title{
Non-contiguous finished genome sequence of Corynebacterium timonense type strain $5401744^{\top}$
}

\author{
Véronique Roux ${ }^{1}$, Catherine Robert ${ }^{1}$ and Didier Raoult ${ }^{1}$. \\ ${ }^{1}$ Aix Marseille Université, Faculté de médecine, Aix-Marseille Université, France \\ *Correspondence: Veronique Roux (veronique.roux@univ-amu.fr) \\ Keywords: Corynebacterium timonense, Actinobacteria
}

Corynebacterium timonense strain $5401744^{\top}$ is a member of the genus Corynebacterium,
which contains Gram-positive bacteria with a high $\mathrm{G}+\mathrm{C}$ content. It was isolated from the
blood of a patient with endocarditis. In this work, we describe a set of features of this organ-
ism, together with the complete genome sequence and annotation. The 2,553,575 bp long
genome contains 2,401 protein-coding genes and 55 RNA genes, including between 5 and 6
rRNA operons.

\section{Introduction}

Corynebacterium timonense strain 5401744T(CSUR $\mathrm{P} 20 \mathrm{~T}=\mathrm{CIP} 109424^{\mathrm{T}}=$ CCUG $53856^{\mathrm{T}}$ ) is the type strain of $C$. timonense. This bacterium was isolated from the blood of a patient with endocarditis [1]. The genus Corynebacterium is comprised of Grampositive facultatively anaerobic bacteria with a high $\mathrm{G}+\mathrm{C}$ content. It currently contains over $80 \mathrm{mem}$ bers [2]. The combination of chemotaxonomic markers [3,4] and a molecular approach based on $16 \mathrm{~S}$ rRNA and rpoB gene sequence analyses improved the identification of members of this genus [5-7]. Corynebacterium species have been isolated from human clinical sources [8-14], animal sources [15-18] and the environment [19-21].

Here we present a summary classification and a set of features for $C$. timonense, together with the description of the non-contiguous finished genomic sequencing and annotation.

\section{Classification and features}

The 16S rRNA gene sequence of C. timonense strain $5401744^{\mathrm{T}}$ was compared with sequences deposited in the Genbank database, confirming the initial taxonomic classification. Figure 1 shows the phylogenetic neighborhood of $C$. timonense in a 16S rRNA based tree.
The bacterium was first characterized in July 2005 , in a 56-year-old man with a history of infective endocarditis. It was isolated from blood culture in the Timone Hospital microbiology laboratory.

Cells are rod-shaped that occur as single cells, in pairs or in small clusters, 0.6-2.1 $\mu \mathrm{m}$ long and 0.4$0.6 \mu \mathrm{m}$ wide. Optimal growth of strain $5401744^{\mathrm{T}}$ occurs at $37^{\circ} \mathrm{C}$ with range for growth between 25 and $50{ }^{\circ} \mathrm{C}$. After 24 hours growth on blood sheep agar at $37^{\circ} \mathrm{C}$, surface colonies are circular, yellow colored, glistening and up to 1-2 $\mathrm{mm}$ in diameter. Carbon sources utilized include glucose and ribose. Activities of catalase, pyrazinamidase, alkaline phosphatase, esterase (C4), esterase lipase (C8), lipase (C14), leucine arylamidase and acid phosphatase are detected. The fatty acid profile is characterized by the predominance of C18:1 $\omega 9 \mathrm{c}$ (36.4\%), C17:1 $\omega 9 \mathrm{c}$ (27.1\%), C16:0 (10.9\%) and C18:0 (6.1\%). Tuberculostearic acid is not detected. The size and ultrastructure of cells were determined by negative staining transmission electron microscopy. The rods were 0.6-2.1 $\mu \mathrm{m}$ long and 0.4-0.6 $\mu \mathrm{m}$ wide (Figure 2). Table 1 presents the classification and features of the organism. 


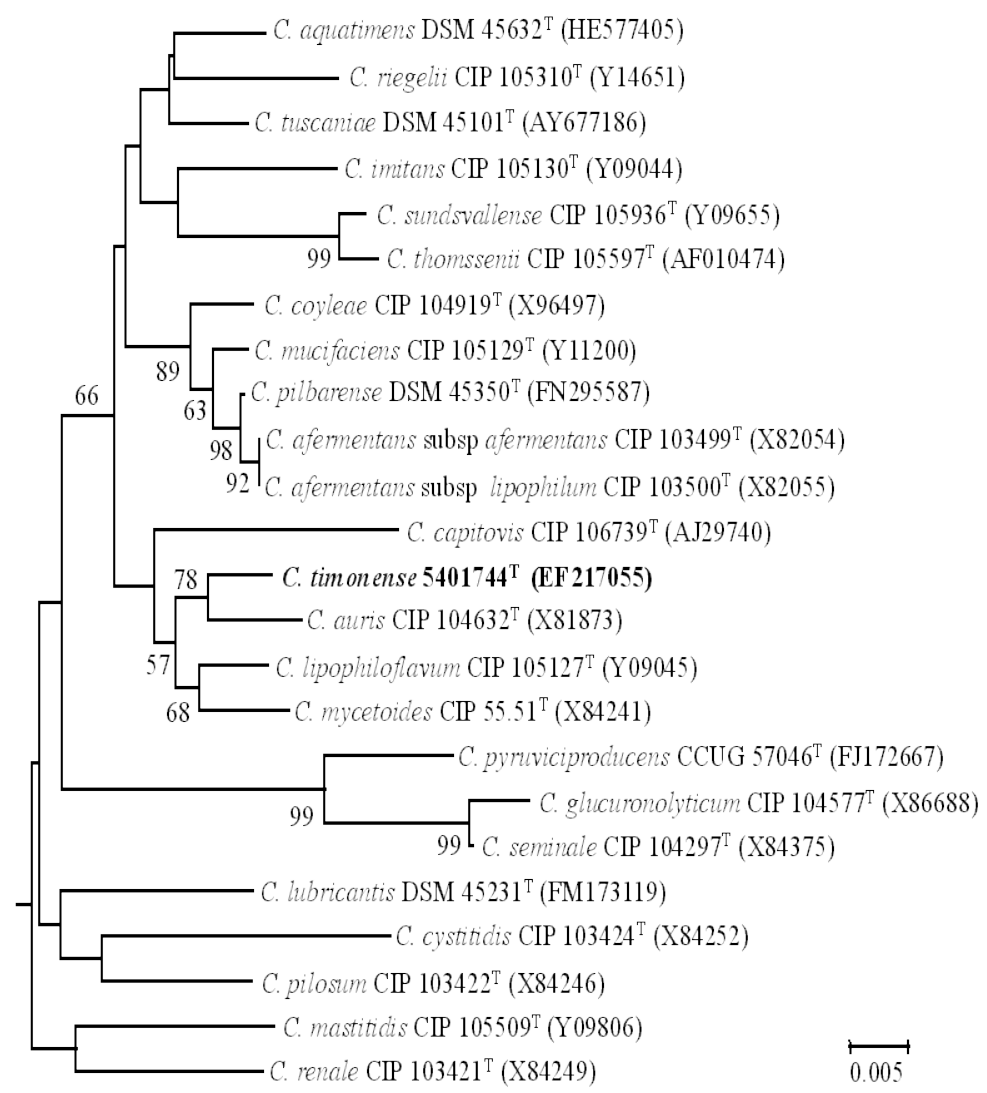

Figure 1. Part of phylogenetic tree highlighting the position of Corynebacterium timonense strain $5401744^{\top}$ relative to other type strains within the Corynebacterium genus by comparison of $16 \mathrm{~S}$ rRNA gene sequences. GenBank accession numbers are indicated in parentheses. Sequences were aligned using CLUSTALX, and phylogenetic inferences obtained using the neighbor joining method within the MEGA 5 software [22]. Numbers at the nodes are percentages of bootstrap values ( $\geq 50 \%$ ) obtained by repeating the analysis 1,000 times to generate a majority consensus tree. Solibacillus silvestris was used as outgroup. The scale bar represents 0.005 nucleotide change per nucleotide position.

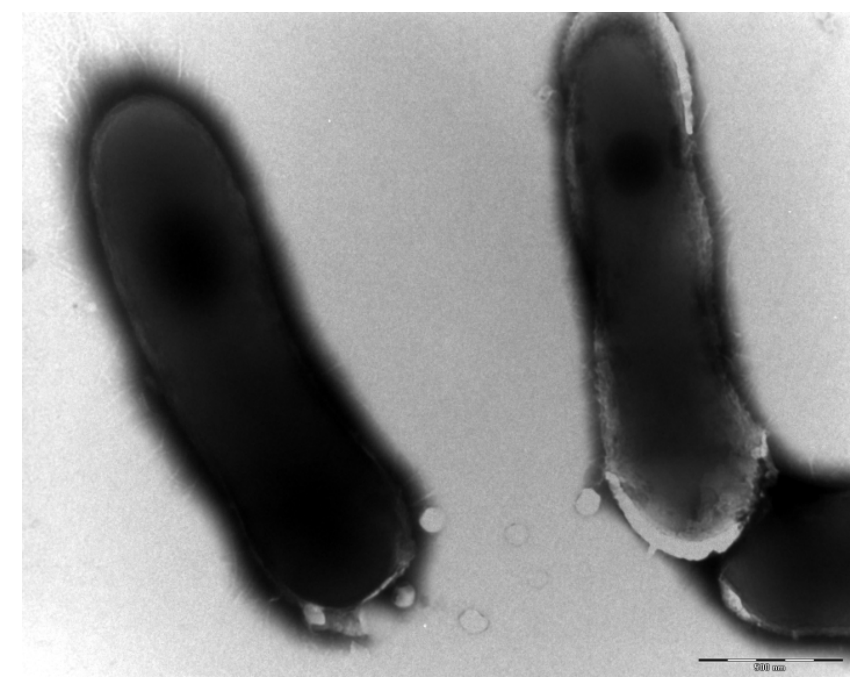

Figure 2. Transmission electron micrograph of $C$. timonense strain $5401744^{\top}$, using a Morgani 268D (Philips) at an operating voltage of $60 \mathrm{kV}$. The scale bar represents $500 \mathrm{~nm}$. 
Table 1. Classification and general features of Corynebacterium timonense strain $5501744^{\top}$

\begin{tabular}{llll}
\hline MIGS ID & Property & Term & Evidence code $^{\mathbf{a}}$ \\
\hline & & Domain Bacteria & TAS $[23]$ \\
& & Phylum Actinobacteria & TAS [24] \\
& Current classification & Order Actinomycetales & TAS [25] \\
& & Family Corynebacteriaceae & TAS $[25-28]$ \\
& & Genus Corynebacterium $[25,26,28,29]$ \\
& & Species Corynebacterium timonense & TAS $[26,30,31]$ \\
& Gram stain & Strain 5401744 ${ }^{\top}$ & TAS $[1]$ \\
& Cell shape & Positive & IDA \\
& Motility & Pleomorphic forms & IDA \\
& Sporulation & Non-motile & IDA \\
& Temperature range & Non-sporulating & IDA \\
& Optimum temperature & Mesophile & IDA \\
MIGS-6.3 3 & Salinity & Not reported & IDA \\
MIGS-22 & Oxygen requirement & Aerobic and facultatively anaerobic & IDA \\
& Carbon source & Glucose, ribose & IDA \\
& Energy source & Chemoorganotroph & NAS \\
MIGS-6 & Habitat & Host & NAS \\
MIGS-15 & Biotic relationship & Free living & IDA \\
MIGS-14 & Pathogenicity & Unknown & IDA \\
& Biosafety level & 2 & NAS \\
& Isolation & Human blood sample & \\
\hline
\end{tabular}

${ }^{a}$ Evidence codes - IDA: Inferred from Direct Assay; TAS: Traceable Author Statement (i.e., a direct report exists in the literature); NAS: Non-traceable Author Statement (i.e., not directly observed for the living, isolated sample, but based on a generally accepted property for the species, or anecdotal evidence). These evidence codes are from the Gene Ontology project [32]. If the evidence is IDA, then the property was directly observed for a live isolate by one of the authors or an expert mentioned in the acknowledgements.

\section{Genome sequencing and annotation Genome project history}

The organism was selected for sequencing on the basis of its phylogenetic position and 16S rRNA similarity to other members of the genus Corynebacterium, and is part of a study of the new species characterized in our laboratory. A sum- mary of the project information is shown in Table 2. The EMBL accession number is CAJP01000000 and consists of 58 contigs ( $\geq 500 \mathrm{bp}$ ) and 10 scaffolds ( $>4,375 \mathrm{bp})$. Table 2 shows the project information and its association with MIGS version 2.0

Table 2. Project information

\begin{tabular}{lll}
\hline MIGS ID & Property & Term \\
\hline MIGS-31 & Finishing quality & High-quality draft \\
MIGS-28 & Libraries used & One paired end 3-kb library and one Shotgun library \\
MIGS-29 & Sequencing platforms & 454 GS FLX Titanium \\
MIGS-31.2 & Fold coverage & $37.2 \times$ \\
MIGS-30 & Assemblers & Newbler version 2.5.3 \\
MIGS-32 & Gene calling method & Prodigal \\
& EMBL ID & CAJP01000000 \\
& EMBL Date of Release & February, 2, 2013 \\
& Project relevance & Study of new species isolated in the URMITE \\
\hline
\end{tabular}




\section{Growth conditions and DNA isolation}

C. timonense strain $5401744^{\mathrm{T}}$, was grown aerobically on $5 \%$ sheep blood-enriched Columbia agar at $37^{\circ} \mathrm{C}$. Five petri dishes were spread and colonies scraped and resuspended in $3 \mathrm{ml}$ of TE buffer. Three hundred $\mu \mathrm{l}$ of $10 \%$ SDS and $150 \mu \mathrm{l}$ of proteinase $\mathrm{K}$ were then added and incubation was performed over-night at $56^{\circ} \mathrm{C}$. The DNA was then extracted using the phenol/chloroform method. The yield and the concentration were measured using the Quant-it Picogreen kit (Invitrogen) on the Genios Tecan fluorometer at $182 \mathrm{ng} / \mu \mathrm{l}$.

\section{Genome sequencing and assembly}

Shotgun and 3-kb paired-end sequencing strategies were performed. The shotgun library was constructed with 500 ng of DNA with the GS Rapid library Prep kit (Roche). For the paired-end sequencing, $5 \mu \mathrm{g}$ of DNA was mechanically fragmented on a Hydroshear device (Digilab) with an enrichment size at 3-4 kb. The DNA fragmentation was visualized using the 2100 BioAnalyzer (Agilent) on a DNA labchip 7500 with an optimal size of $3.5 \mathrm{~kb}$. The library was constructed according to the 454 GS FLX Titanium paired-end protocol. Circularization and nebulization were performed and generated a pattern with an optimal size of 501 bp. After PCR amplification through 15 cycles followed by double size selection, the single stranded paired-end library was then quantified using the Genios fluorometer (Tecan) at 2,540 pg/ $\mu \mathrm{L}$. The library concentration equivalence was calculated as $9.30 \mathrm{E}+09$ molecules/ $\mu \mathrm{L}$. The library was stored at $-20^{\circ} \mathrm{C}$ until further use.

The shotgun and paired-end libraries were clonally-amplified with $2 \mathrm{cpb}$ and $1 \mathrm{cpb}$ in $3 \mathrm{SV}$-emPCR reactions with the GS Titanium SV emPCR Kit (LibL) v2 (Roche). The yields of the emPCR were $11.5 \%$ and $7.92 \%$, respectively, in the 5 to $20 \%$ range from the Roche procedure. Approximately 790,000 beads for the shotgun application and for the $3 \mathrm{~kb}$ paired end were loaded on the GS Titanium PicoTiterPlate PTP Kit 70x75 and sequenced with the GS FLX Titanium Sequencing Kit XLR70 (Roche). The run was performed overnight and then analyzed on the cluster through the gsRunBrowser and Newbler assembler (Roche). A total of 252,118 passed filter wells were obtained and generated $37.19 \mathrm{Mb}$ with a length average of
$366.5 \mathrm{bp}$. The passed filter sequences were assembled using Newbler with $90 \%$ identity and 40 bp as overlap. The final assembly identified 10 scaffolds and 46 large contigs $(>1,500 \mathrm{bp})$.

\section{Genome annotation}

Open Reading Frames (ORFs) were predicted using Prodigal [33] with default parameters but the predicted ORFs were excluded if they spanned a sequencing GAP region. The predicted bacterial protein sequences were searched against the GenBank database [34] and the Clusters of Orthologous Groups (COG) database [35] using BLASTP. The tRNAscan-SE tool [36] was used to find tRNA genes, whereas ribosomal RNAs were found by using RNAmmer [37].

Transmembrane domains and signal peptides were predicted using TMHMM [38] and SignalP [39], respectively. ORFans were identified if their BLASTp $E$-value was lower than 1e-03 for alignment length greater than 80 amino acids. If alignment lengths were smaller than 80 amino acids, we used an $E$-value of $1 \mathrm{e}-05$. Such parameter thresholds have been used in previous works to define ORFans.

To estimate the mean level of nucleotide sequence similarity at the genome level between $C$. timonense and the Corynebacterium genomes available to date, we compared the ORFs only using comparison sequence based in the server RAST [40] at a query coverage of $\geq 60 \%$ and a minimum nucleotide length of $100 \mathrm{bp}$.

\section{Genome properties}

The genome is 2,553,575 bp long with a $66.85 \%$ GC content (Table 3, Figure 3). Of the 2,456 predicted genes, 2,401 were protein-coding genes, and 55 were RNAs. A total of 1,779 genes (74.09\%) were assigned a putative function, and 116 genes were identified as ORFans (4.83\%). The remaining genes were annotated as hypothetical proteins (369 genes (15.37\%)). The remaining genes were annotated as either hypothetical proteins or proteins of unknown function. The distribution of genes into COGs functional categories is presented in Table 4. The properties and the statistics of the genome are summarized in Tables 3 and 4. 


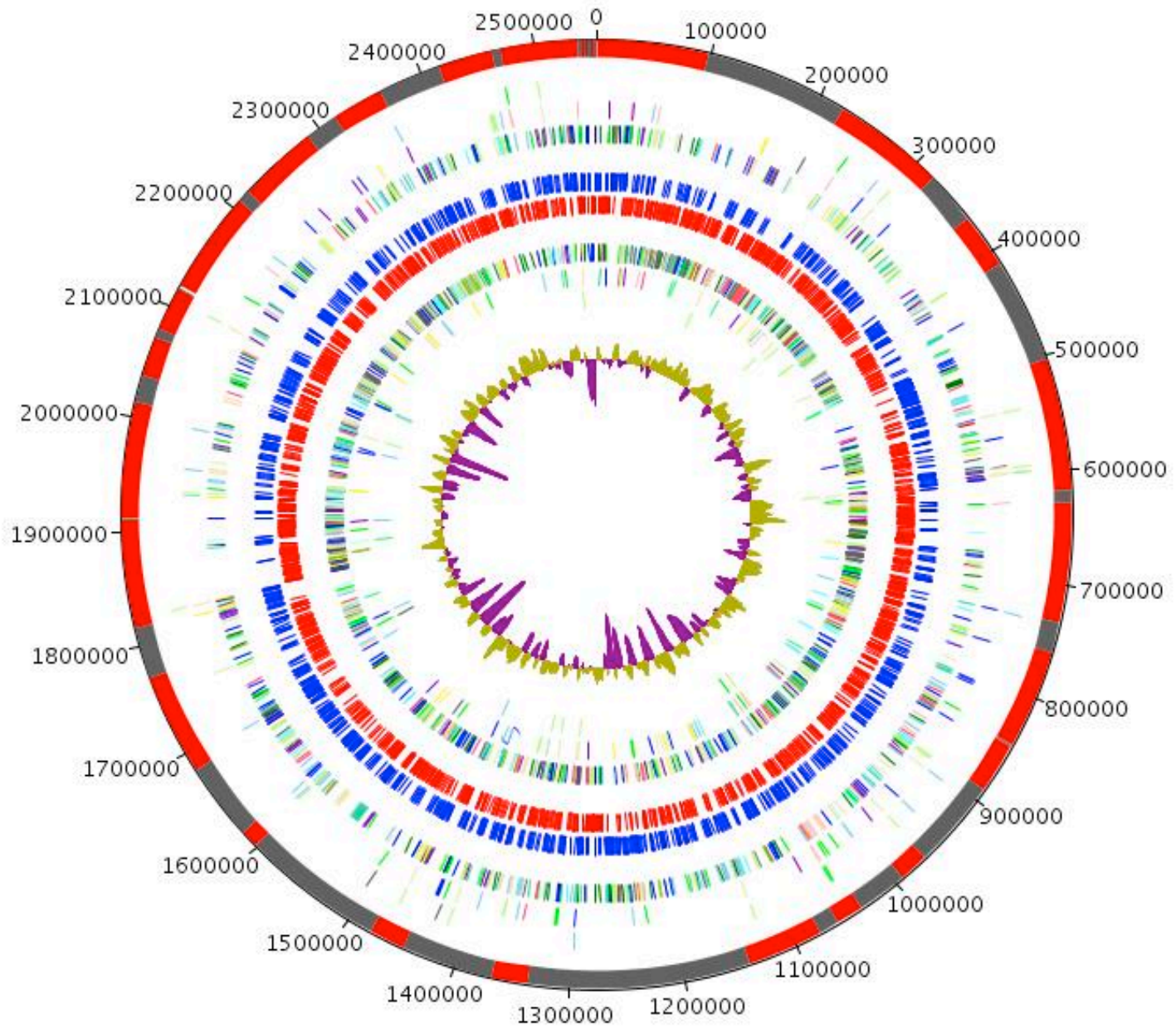

Figure 3. Graphical circular map of Corynebacterium timonense genome. From outside to the center: Contigs (red / grey), COG category of genes on the forward strand (three circles), genes on forward strand (blue circle), genes on the reverse strand (red circle), COG category on the reverse strand (three circles), GC content.

Table 3. Nucleotide content and gene count levels of the genome

\begin{tabular}{lll}
\hline Attribute & Value & \% of total \\
\hline Genome size (bp) & $2,553,575$ & 100 \\
DNA coding region (bp) & $2,289,384$ & 89.65 \\
DNA G+C content (bp) & $1,707,056$ & 66.85 \\
Total genes & 2,456 & 100 \\
RNA genes & 55 & 2.24 \\
Protein-coding genes & 2,401 & 97.76 \\
Genes with function prediction & 1,779 & 74.09 \\
Genes assigned to COGs & 1,753 & 73.01 \\
Genes with peptide signals & 353 & 14.7 \\
Genes with transmembrane helices & 550 & 22.91 \\
\hline
\end{tabular}

${ }^{a}$ The total is based on either the size of the genome in base pairs or the total number of protein coding genes in the annotated genome 
Table 4. Number of genes associated with the 25 general COG functional categories

\begin{tabular}{|c|c|c|c|}
\hline Code & Value & $\%$ of total ${ }^{a}$ & Description \\
\hline$J$ & 148 & 6.16 & Translation \\
\hline A & 1 & 0.04 & RNA processing and modification \\
\hline K & 136 & 5.66 & Transcription \\
\hline $\mathrm{L}$ & 179 & 7.46 & Replication, recombination and repair \\
\hline B & 0 & 0 & Chromatin structure and dynamics \\
\hline $\mathrm{D}$ & 17 & 0.71 & Cell cycle control, mitosis and meiosis \\
\hline Y & 0 & 0 & Nuclear structure \\
\hline $\mathrm{V}$ & 45 & 1.87 & Defense mechanisms \\
\hline $\mathrm{T}$ & 62 & 2.58 & Signal transduction mechanisms \\
\hline M & 89 & 3.71 & Cell wall/membrane biogenesis \\
\hline $\mathrm{N}$ & 2 & 0.08 & Cell motility \\
\hline Z & 0 & 0 & Cytoskeleton \\
\hline W & 0 & 0 & Extracellular structures \\
\hline U & 27 & 1.12 & Intracellular trafficking and secretion \\
\hline $\mathrm{O}$ & 60 & 2.50 & Posttranslational modification, protein turnover, chaperones \\
\hline $\mathrm{C}$ & 97 & 4.04 & Energy production and conversion \\
\hline G & 121 & 5.04 & Carbohydrate transport and metabolism \\
\hline $\mathrm{E}$ & 205 & 8.54 & Amino acid transport and metabolism \\
\hline $\mathrm{F}$ & 65 & 2.71 & Nucleotide transport and metabolism \\
\hline $\mathrm{H}$ & 100 & 4.16 & Coenzyme transport and metabolism \\
\hline I & 78 & 3.25 & Lipid transport and metabolism \\
\hline $\mathrm{P}$ & 176 & 7.33 & Inorganic ion transport and metabolism \\
\hline Q & 46 & 1.92 & Secondary metabolites biosynthesis, transport and catabolism \\
\hline $\mathrm{R}$ & 233 & 9.7 & General function prediction only \\
\hline $\mathrm{S}$ & 137 & 5.71 & Function unknown \\
\hline$x$ & 648 & 26.99 & Not in COGs \\
\hline
\end{tabular}

aThe total is based on the total number of protein coding genes in the annotated genome.

\section{Comparison with other Corynebacterium genomes}

To date, 13 genomes of species belonging to the genus Corynebacterium have been sequenced. The size of the whole genomes was between $2.32 \mathrm{Mb}$ and $3.43 \mathrm{Mb}$ (Table 5). The gene number was correlated with the genome size and was between 2,187 and 3,131 . The $\mathrm{G}+\mathrm{C}$ content of the genome was less than $60 \%$ for $C$. diphtheriae, $C$. glutamicum, C. kroppenstedtii, C. pseudotuber- culosis, C. resistens and C. ulcerans but was more than $60 \%$ for $C$. aurimucosum, C. efficiens, $C$. genitalium, C. halotolerans, C. jeikeium, C. timonense, C. urealyticum and C. variabile. $C$. timonense shared a mean sequence similarity of $72.05 \% \quad$ (60-99.01\%), $72.15 \% \quad(60.09-97.54 \%)$, $74.63 \% \quad(60-98.37 \%), \quad 71.83 \% \quad(60-98.85 \%)$, $72.34 \%(60-98.02 \%)$ and $71.70 \%(60-97.03 \%)$ with C. diphtheriae, C. efficiens, C. genitalium, C. 
glutamicum, C. jeikeium and C. urealyticum, respec- tively.

Table 5. Comparison of $C$. timonense characteristics with Corynebacterium whole genome characteristics.

\begin{tabular}{lccc}
\hline Species & Genome size $\mathbf{( M b )}$ & $\mathbf{G + C} \%$ & Number of predicted genes \\
\hline C. arimucosum & 2.82 & 60.5 & 2,630 \\
C.diphtheriae & 2.48 & 53.5 & 2,392 \\
C. efficiens & 3.22 & 62.9 & 3,064 \\
C. genitalium & 2.35 & 62.7 & 2,290 \\
C. glutamicum & 3.31 & 53.9 & 3,122 \\
C. halotolerans & 3.22 & 68.3 & 2,930 \\
C. jeikeium & 2.48 & 61.4 & 2,181 \\
C. kroppenstedtii & 2.45 & 57.5 & 2,083 \\
C. pseudotuberculosis & 2.32 & 52.2 & 2,187 \\
C. resistens & 2.60 & 57.1 & 2,230 \\
C. timonense & 2.55 & 66.7 & 2,456 \\
C. ulcerans & 2.56 & 53.4 & 2,355 \\
C. urealyticum & 2.36 & 64.2 & 2,045 \\
C. variabile & 3.43 & 67.1 & 3,131 \\
\hline
\end{tabular}

\section{Prophage genome properties}

Prophage Finder [41] and PHAST [42] were used to identify potential proviruses in C. timonense strain $5401744^{\mathrm{T}}$ genome. The bacteria contains at least one genetic element of around $40.3 \mathrm{~kb}$ (with a GC content of $64.9 \%$ ), we named CT1, on contigs 6-7. A total of 53 open reading frames (ORFs) were recovered from CT1, that were longer than 55 amino acids and most of them (44) encode proteins sharing a high identity with proteins found

\section{Acknowledgments}

The authors thank Mr. Julien Paganini at Xegen Company (www.xegen.fr) for automating the ge-

\section{References}

1. Merhej V, Falsen E, Raoult D, Roux V. Corynebacterium timonense sp. nov. and Corynebacterium massiliense sp. nov., isolated from human blood and human articular hip fluid. Int J Syst Evol Microbiol 2009; 59:1953-1959. PubMed http://dx.doi.org/10.1099/ijs.0.005827-0

2. Euzéby JP. List of Bacterial Names with Standing in Nomenclature: a folder available on the Internet. Int / Syst Bacteriol 1997; 47:590-592. PubMed http://dx.doi.org/10.1099/00207713-47$2-590$

3. Collins MD, Goodfellow M, Minnikin DE. A survey of the structures of mycolic acids in in Actinomycetales order viruses. The preliminary annotation of CT1 was performed and the majority of the putative genes (41) encode hypothetical proteins. The ORFs with an attributed function (12) encode proteins involved in DNA packaging, cell lysis, tail structural components and assembly, head structural components and assembly, lysogeny control, DNA replication, recombination and modification. 47 of the ORFs are located on one strand and 6 on the opposite strand.

nomic annotation process and Laetitia Pizzo for her technical assistance.

Corynebacterium and related taxa. / Gen

Microbiol 1982; 128:129-149. PubMed

4. von Graevenitz A, Punter V, Gruner E, Pfyffer GE, Funke G. Identification of coryneform and other gram-positive rods with several methods. APMIS 1994; 102:381-389. PubMed http://dx.doi.org/10.1111/j.16990463.1994.tb04887.x

5. Khamis A, Raoult D, La Scola B. rpoB gene sequencing for identification of Corynebacterium species. J Clin Microbiol 2004; 42:3925-3931. PubMed http://dx.doi.org/10.1128/JCM.42.9.3925$\underline{3931.2004}$ 
6. Pascual C, Lawson PA, Farrow JA, Gimenez MN, Collins MD. Phylogenetic analysis of the genus Corynebacterium based on 16S rRNA gene sequences. Int J Syst Bacteriol 1995; 45:724-728. PubMed http://dx.doi.org/10.1099/00207713-454-724

7. Rainy R, Riegel P, Boiron P, Monteil H, Christen R. Phylogeny of the genus Corynebacterium deduced from analyses of small-subunit ribosomal DNA sequences. Int I Syst Bacteriol 1995;

45:740-746. PubMed http://dx.doi.org/10.1099/00207713-45-4-740

8. Feurer $\mathrm{C}$, Clermont $\mathrm{D}$, Bimet $\mathrm{F}$, Candrea A, Jackson M, Glaser P, Bizet C, Dauga C. Taxonomic characterization of nine strains isolated from clinical and environmental specimens, and proposal of Corynebacterium tuberculostearicum sp. nov. Int J Syst Evol Microbiol 2004; 54:1055-1061. PubMed http://dx.doi.org/10.1099/ijs.0.02907-0

9. Funke G, Lawson PA, Collins MD. Heterogeneity within human-derived centers for disease control and prevention (CDC) coryneform group ANF-1like bacteria and description of Corynebacterium auris sp. nov. Int J Syst Bacteriol 1995; 45:735739. PubMed http://dx.doi.org/10.1099/00207713-45-4-735

10. Funke G, Hutson RA, Hilleringmann M, Heizmann WR, Collins MD. Corynebacterium lipophiloflavum sp. nov. isolated from a patient with bacterial vaginosis. FEMS Microbiol Lett 1997; 150:219-224. PubMed http://dx.doi.org/10.1016/S0378-1097(97)00118$\underline{3}$

11. Funke G, Lawson PA, Collins MD. Corynebacterium mucifaciens sp. nov., an unusual species from human clinical material. Int J Syst Bacteriol 1997; 47:952-957. PubMed http://dx.doi.org/10.1099/00207713-47-4-952

12. Funke G, Osorio CR, Frei R, Riegel P, Collins MD. Corynebacterium confusum sp. nov., isolated from human clinical specimens. Int / Syst Bacteriol 1998; 48:1291-1296. PubMed http://dx.doi.org/10.1099/00207713-48-4-1291

13. Riegel $P$, Creti $R$, Mattei $R$, Nieri A, von Hunolstein C. Isolation of Corynebacterium tuscaniae sp. nov. from blood cultures of a patient with endocarditis. J Clin Microbiol 2006; 44:307312. PubMed http://dx.doi.org/10.1128/JCM.44.2.307-312.2006

14. Yassin AF. Corynebacterium ureicelerivorans sp. nov., a lipophilic bacterium islated from blood culture. Int J Syst Evol Microbiol 2007; 57:12001203. PubMed http://dx.doi.org/10.1099/ijs.0.64832-0
15. Collins MD, Hoyles L, Foster G, Sjoden B, Falsen E. Corynebacterium capitovis sp. nov., from a sheep. Int J Syst Evol Microbiol 2001; 51:857-860. PubMed http://dx.doi.org/10.1099/00207713-51$\underline{\text { 3-857 }}$

16. Collins MD, Hoyles L, Foster G, Falsen E. Corynebacterium caspium sp. nov., from a Caspian seal (Phoca caspica). Int I Syst Evol Microbiol 2004; 54:925-928. PubMed http://dx.doi.org/10.1099/ijs.0.02950-0

17. Fernández-Garayzábal M, Collins MD. Corynebacterium ciconiae sp. nov., isolated from the trachea of black storks (Ciconia nigra). Int J Syst Evol Microbiol 2004; 54:2191-2195. PubMed http://dx.doi.org/10.1099/ijs.0.63165-0

18. Vela Al, Mateos A, Collins MD, Briones V, Hutson RA, Dominguez L, Fernandez-Garayzabal JF. Corynebacterium suicordis sp. nov., from pigs. Int J Syst Evol Microbiol 2003; 53:2027-2031. PubMed http://dx.doi.org/10.1099/ijs.0.02645-0

19. Chen HH, Li WJ, Tang SK, Kroppenstedt RM, Stackebrandt E, Xu LH, Jiang CL.

Corynebacterium halotolerans sp. nov., isolated from saline soil in the west of China. Int J Syst Evol Microbiol 2004; 54:779-782. PubMed http://dx.doi.org/10.1099/ijs.0.02919-0

20. Fudou R, Jojima $Y$, Seto A, Yamada K, Kimura E, Nakamatsu T, Hiraishi A, Yamanaka S.

Corynebacterium efficiens sp. nov., a glutamicacid-producing species from soil and vegetables. Int J Syst Evol Microbiol 2002; 52:1127-1131. PubMed http://dx.doi.org/10.1099/ijs.0.02086-0

21. Zhou Z, Yuan M, Tang R, Chen M, Lin M, Zhang W. Corynebacterium deserti sp. nov., isolated from desert sand. Int I Syst Evol Microbiol 2012; 62:791-794. PubMed http://dx.doi.org/10.1099/ijs.0.030429-0

22. Tamura K, Peterson D, Peterson N, Stecher G, Nei M, Kumar S. MEGA5: Molecular Evolutionary Genetics Analysis using Maximum Likelihood, Evolutionary Distance, and Maximum Parsimony Methods. Mol Biol Evol 2011; 28:2731-2739. PubMed http://dx.doi.org/10.1093/molbev/msr121

23. Woese CR, Kandler O, Wheelis ML. Towards a natural system of organisms: proposal for the domains Archaea, Bacteria, and Eucarya. Proc Natl Acad Sci USA 1990; 87:4576-4579. PubMed http://dx.doi.org/10.1073/pnas.87.12.4576

24. Garrity GM, Holt JG. The Road Map to the Manual. In: Garrity GM, Boone DR, Castenholz RW (eds), Bergey's Manual of Systematic Bacteriology, Second Edition, Volume 1, Springer, New York, 2001, p.119-169. 